\title{
Sedimentation Influence on Magnetorheological Brake Torque Moment
}

\author{
J. Věžys, ${ }^{\text {a,1 }}$ D. Mažeika, ${ }^{\text {a,2 }}$ R. Kandrotaitė-Janutienė, ${ }^{\text {a,3 }}$ E. Dragašius, ${ }^{\text {a,4 }}$ A. Kilikevičius, ${ }^{\text {b,5 }}$ \\ and E. V. Korobko c,6 \\ a Kaunas University of Technology, Kaunas, Lithuania \\ ${ }^{\mathrm{b}}$ Vilnius Gediminas Technical University, Vilnius, Lithuania \\ ${ }^{\mathrm{c}}$ Luikov Heat and Mass Transfer Institute, National Academy of Sciences of Belarus, Minsk, Belarus \\ 1 joris.vezys@ktu.edu \\ 2 darius.mazeika@ktu.lt \\ 3 raskand@ktu.lt \\ ${ }^{4}$ egidijus.dragasius@ktu.lt \\ 5 arturas.kilikevicius@vgtu.lt \\ 6 evkorobko@gmail.com
}

УДК 539.4

\section{Экспериментальное исследование вязкого трения и крутящего момента магнитореологического тормоза с учетом эффекта седиментации в различных магнитореологических жидкостях}

\author{
Ж. Вежис ${ }^{\mathrm{a}}$, Д. Мажейка ${ }^{\mathrm{a}}$ Р. Кандротайте-Жанутиене ${ }^{\mathrm{a}}$, Е. Драгашюс \\ А. Киликевичюс ${ }^{\sigma}$, Е. В. Коробко \\ a Каунасский технологический университет, Каунас, Литва \\ ${ }^{\sigma}$ Вильнюсский технический университет им. Гедиминаса, Вильнюс, Литва

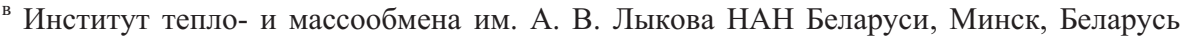

Исследуется влияние осаждения в магнитореологической жидкости на вязкое трение и крутящий момент магнитореологического тормоза. Протестировано пять различных магнитореологических жидкостей: MRF-140CG и MRF-122EG (корпорация Lord, CША), MRHCCS4-A и MRHCCS4-B (компания Liquids, Великобритания) и MUDZH-3 (Ин-m тепло- и массообмена им. А. В. Лыкова НАН Беларуси). Вязкость магнитореологических жидкостей в магнитном поле интенсивностью 0-1 T измеряли реометром типа Anton Paar Physica MCR-301. Для использования в магнитореологическом тормозе была выбрана жидкость с лучшими параметрами. Седиментацию в магнитореологической жидкости определяли запатентованным авторами методом, основанным на измерении электросопротивления жидкости. Разработана математическая модель вязкого трения и седиментации в зависимости от электросопротивления жидкости. Для смешивания жидкостей внутри магнитореологического тормоза использовали четыре пьезопривода. Создана экспериментальная установка для определения крутящчего момента тормоза.

Ключевые слова: магнитореологические жидкости, магнитореологический тормоз, седиментация, реометр, пьезоприводы, вязкость, электросопротивление.

(C) J. VĖŽYS, D. MAŽEIKA, R. KANDROTAITĖ-JANUTIENĖ, E. DRAGAŠIUS, A. KILIKEVIČIUS, E. V. KOROBKO, 2018 
Introduction. Magnetorheological (MR) fluids is a type of smart fluids, which consist of carrying fluid (usually oil, grease, lubricant, etc.) and micron-sized ferromagnetic particles. These fluids were great investigated because of their ability to change their state from liquid to solid and vice versa in a couple of milliseconds. When the magnetic field is applied on the fluid, its particles become polarized and arrange into the chains, because of that shear stress and viscosity of the fluid increase [1-3]. Controllable strength of these fluids can be used in some devices as MR brakes, MR clutches, MR shock absorbers, etc. [4-9]. This makes MR fluids quite attractive new generation smart materials. Despite the great success of these fluids, there is not much reports on the MR fluid electrical resistivity. Its electrical resistivity depends on these parameters: temperature, how much time magnetic field is applied on MR fluid, concentration of particles in MR fluid, sedimentation and magnetic field strength [10-13]. When magnetic field is applied on MR fluid, its resistivity decreases until its saturation and then remains constant.

One of the biggest problems with MR fluids is settlement of their particles (sedimentation) [11, 14-16]. If fluid has not been used for a long time, the sedimentation occurs. In scientific data there are described a couple ways to determine sedimentation [17-19]. In this work have been used patent pending technology to determine sedimentation in MR fluid - with special created sensors measuring their electrical resistivity.

1. Theoretical Background. The magnetization of magnetic particles in MR fluid can be described as [16]:

$$
M=\rho_{p} m L(\xi)
$$

where

$$
L(\xi)=1-\frac{1}{\xi}
$$

It is a Langevin function. The $\xi$ can be described as [20]:

$$
\xi=\frac{\pi}{6} \frac{\mu_{0} M_{s} a^{3} H}{k T} .
$$

Then the magnetization of MR fluid can be described as [16]:

$$
M=M_{s}\left(1-\frac{6 k T}{\pi \mu_{0} M_{s} a^{3} H}\right)=M_{s}\left(1-\frac{1}{\xi}\right),
$$

where

$$
\begin{gathered}
M_{s}=\rho_{p} m, \\
\rho_{p}=\frac{M_{s}}{m} .
\end{gathered}
$$

The motion equation of two dipoles which are between measuring electrodes can be described as

$$
\frac{\pi}{6} a^{3} \rho \frac{d^{2} x}{d t^{2}}+3 \pi \eta a \frac{d x}{d t}+\frac{\pi}{6} \mu_{0} a^{3} M \delta=0 .
$$
is

Using initial conditions $x=x_{\max }$, when $t=0$ and $H \neq 0$ the solution for Eq. (7) 


$$
x=x_{\max }-\frac{\mu_{0} M}{18 \eta} \delta a^{2} t .
$$

Using Eq. (4) and knowing that, when $T=300 \mathrm{~K}, 6 k T$ a lot of smaller than $\pi \mu_{0} M_{s} a^{3} H$, we can obtain

$$
x=x_{\max }-\frac{\mu_{0} M_{s}}{18 \eta} \delta a^{2} t
$$

or

$$
x=x_{\max }-\frac{k T \xi}{3 \pi a \eta H} .
$$

Using the solutions of Eqs. (9) and (10), equivalent electrical resistivity of the MR fluid resistor can be described as

$$
R=\frac{2 \rho_{m}}{3 \pi \varphi a l}\left(x_{\max }-\frac{\mu_{0} M_{s}}{18 \eta} \delta a^{2} t\right) .
$$

This can be expressed as

$$
R=R(t)=R_{\max }-\frac{\rho_{m} \mu_{0} M_{s}}{27 \pi l \eta} a \delta t,
$$

or

$$
R=R(t)=R_{\max }-\frac{2 \rho_{m} t \delta k T \xi}{9 \pi^{2} \ln a H},
$$

where

$$
R_{\max }=\frac{2 \rho_{m} x_{\max }}{3 \pi a l \varphi}
$$

Using the Navier-Stokes law, the velocity of sedimentation (settling velocity) of the particles depends on the difference between the weight and buoyancy of the particle and can be described as

$$
F_{g}=\left(\rho_{p}-\rho_{t}\right) g \frac{4}{3} \pi a^{3}
$$

where $\rho_{p}$ is the mass density of the particle, $\rho_{t}$ is the mass density of carrier liquid, $g$ is gravitational acceleration, and $a$ is radius of the magnetic particle.

The force of viscosity on a small sphere moving through a viscous fluid can be written as

$$
F_{d}=6 \pi \eta a v
$$

where $F_{d}$ is the frictional force, $\eta$ is the dynamic viscosity, and $v$ is flow velocity.

Requiring the force balance $F_{d}=F_{g}$ and solving for the velocity $v$ gives the terminal velocity $v_{s}$. Note that since buoyant force increases as $a^{3}$ and Stokes' drag increases as $a$, the terminal velocity increases as $a^{2}$ and thus varies greatly with particle size as shown below. If the particle is falling in the viscous fluid under its own weight, then 
a terminal velocity, or settling velocity, is reached when this frictional force combined with the buoyant force exactly balances the gravitational force. This velocity can be written as

$$
v_{s}=\frac{2}{9} \frac{\left(\rho_{p}-\rho_{t}\right)}{\eta} g a^{2},
$$

where the notations used are described above.

The sedimentation coefficient $s$ of a particle is used to characterize its behavior in sedimentation processes. It is defined as the ratio of a particle's sedimentation velocity $v_{S}$ to the gravitational and can be described as

$$
s=\frac{v_{s}}{g} .
$$

A Svedberg unit (symbol $S$, sometimes $S v$ ) is a non-metric unit for sedimentation rate. The sedimentation rate for a particle of a given size and shape measures how fast the particle 'settles', the sedimentation. The Svedberg unit is actually a measure of time, it is defined as exactly $10^{-13}$ seconds.

Putting Eq. (17) into Eq. (18) it can be described as

$$
s=\frac{v_{s}}{g}=\frac{2}{9} \frac{\left(\rho_{p}-\rho_{t}\right)}{\eta} a^{2} .
$$

Instead of mass density of the particle putting the expression from the Eq. (3) it can be described as

$$
s=\frac{v_{s}}{g}=\frac{2}{9} \frac{\left(\frac{M_{s}}{m}-\rho_{t}\right)}{\eta} a^{2} .
$$

Then we can get the expression of $M_{s}$ :

$$
M_{s}=m\left(\rho_{t}+\frac{9 S \eta}{2 a^{2}}\right)=\frac{9 S \eta m}{2 a^{2}}+\rho_{t} m
$$

Substituting the result into Eq. (11), we get

$$
R=R(S)=\frac{2 \rho_{m} x_{\max }}{3 \pi l \varphi a}-\frac{\rho_{m} \mu_{0} m\left(2 a^{2} \rho_{t}+9 S \eta\right)}{54 \pi l \eta a^{2}} a \delta t .
$$

2. Methodology. Five different magnetorheological fluids (MRF-140CG and MRF122EG from Lord Corporation, USA, MRHCCS4-A and MRHCCS4-B are from Liquids Research Company, UK, and MUDZH-3, made in Luikov Heat and Mass Transfer Institute, Belarus) were tested. The viscosity of these magnetorheological fluids in the magnetic field of 0-1 T was measured on the Anton Paar Physica MCR-301 rheometer. Concentration of particles in different magnetorheological fluids was taken from their manufactures internet resources and is presented in Table 1.

Newly designed magnetorheological brake was filled with MRHCCS4-B. Scheme of magnetorheological brake is shown in Fig. 1. This brake consists of disc 7 which is placed inside magnetorheological fluid 11. Induction coil 4 is wrapped about the magnetic 
J. Vèžys, D. Mažeika, R. Kandrotaitè-Janutienè, et al.

$\mathrm{T}$ a b 1 e 1

Concentration of Particles in Different Magnetorheological Fluids [21-23]

\begin{tabular}{|c|c|}
\hline MR fluid & Concentration of particles (\%) \\
\hline MRF-140CG & 85 \\
\hline MRF-122EG & 72 \\
\hline MRHCCS4-A & 70 \\
\hline MRHCCS4-B & 80 \\
\hline MUDZH-3 & 71 \\
\hline
\end{tabular}

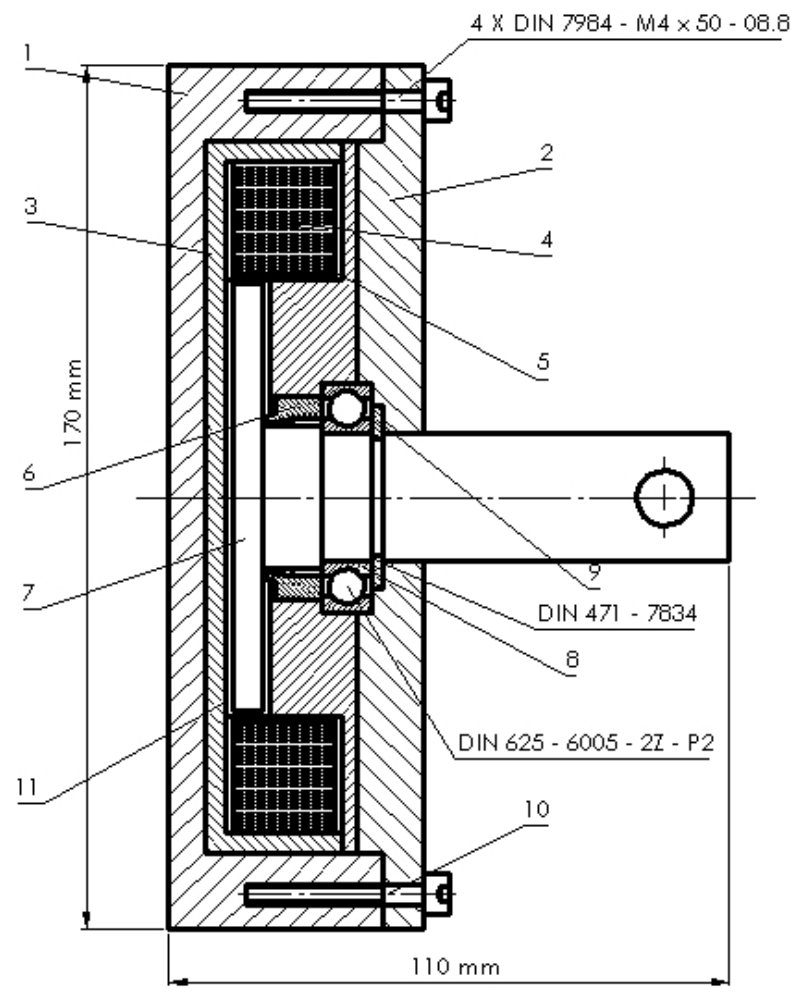

Fig. 1. Brake with magnetorheological fluid: (1) body, (2) body cap, (3) magnetic conductor, (4) induction coil, (5) induction coil frame, (6) sealant, (7) disc, (8) bearing, (9) locking ring, (10) bolts, and (11) MR fluid.

conductor 3, and when current is applied it creates a magnetic field. Conductor, the coil frame and disc was made of magnetic conductible metal - steel S235JR. Other parts were made from aluminum. Bearing 8 lets disc rotate inside the brake. Sealant 6 with locking ring 8 don not let magnetorheological fluid leak out form the brake.

The magnetic conductor of this brake was improved by patent pending technology to determine sedimentation in magnetorheological fluids measuring their electric resistivity. Two resistivity sensors were placed, in the top and the bottom of construction. Also four piezo-actuators were placed to mix the fluid inside the brake if the sedimentation occurs. Scheme of modified conductor is shown in Fig. 2.

Using the modified MR brake, the experimental setup for measure its torque moment was created. Motor 5 was connected to MR brake 4 and was powered by power supply 1 . 


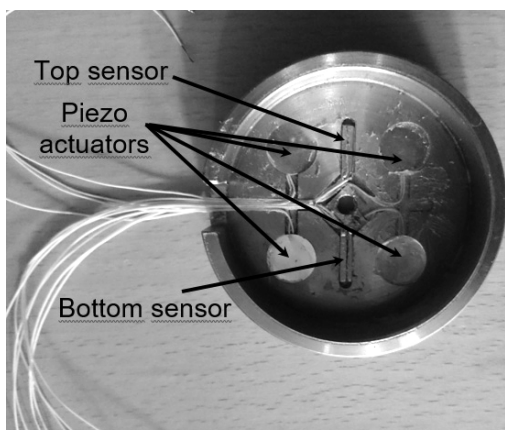

a

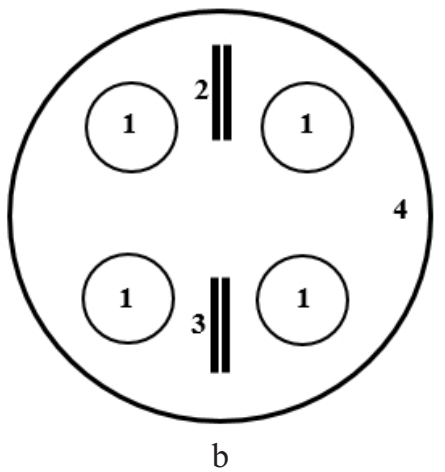

b

Fig. 2. Magnetic conductor of MR brake: (a) real view; (b) schematic view. The conductor (4) was modified by adding four piezo-actuators (1) and two resistivity measuring sensors (2) and (3) for determining of sedimentation.

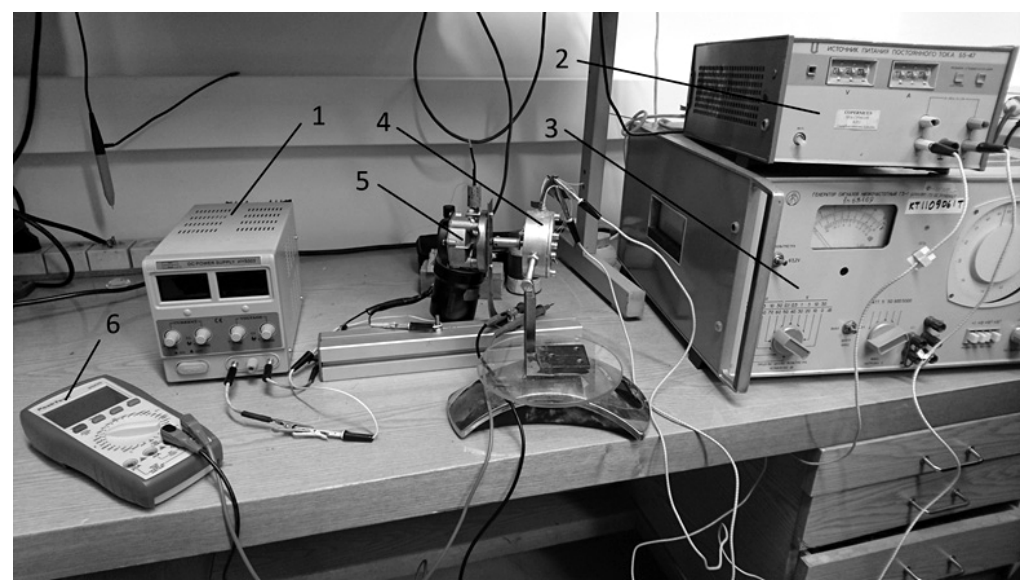

Fig. 3. Experimental setup: (1) power supply for motor, (2) power supply for MR brake, (3) frequency generator, (4) MR brake, (5) motor, and (6) multimeter.

The coil of MR brake was powered by power supply 2 and magnetic field was created. Sedimentation level in the brake was determined by measuring electric resistivity of the fluid inside brake by multimeter PeakTech 2005, which can detect resistivity up to 2 G $\Omega$. When sedimentation occurred, 4 piezo-actuators were powered by frequency generator 3 at $2 \mathrm{kHz}$. Experimental setup is shown in the Fig. 3.

3. Results and Discussion. To select the appropriate fluid to fill up a newly created device, the viscosity of five different fluids were measured using the rheometer. This parameter is one of the main characteristics of MR fluids, but not all manufacturers share this information with their customers. There are written some articles about viscosity dependence on share rate [24]. Mostly, own made MR fluids are tested, but in this case manufactured and market available MR fluids have been tested. Also, in real working applications of MR fluids it is critically important to know, how much power device could provide using a fluid. Because of sedimentation this power decreases, even if the fluids' viscosity is quite large when applying the magnetic field to it.

3.1. Measuring of Viscosity Using Rheometer. Firstly, viscosity dependence on shear rate was measured without magnetic field. Results are shown in Fig. 4.

From chart can be seen the highest viscosity when no magnetic field is applied was on the fluid MUDZH-3. Both fluids from Liquids research company has probably the same viscosity. MRF-122EG magnetorheological fluid has noticeable lower viscosity than other 


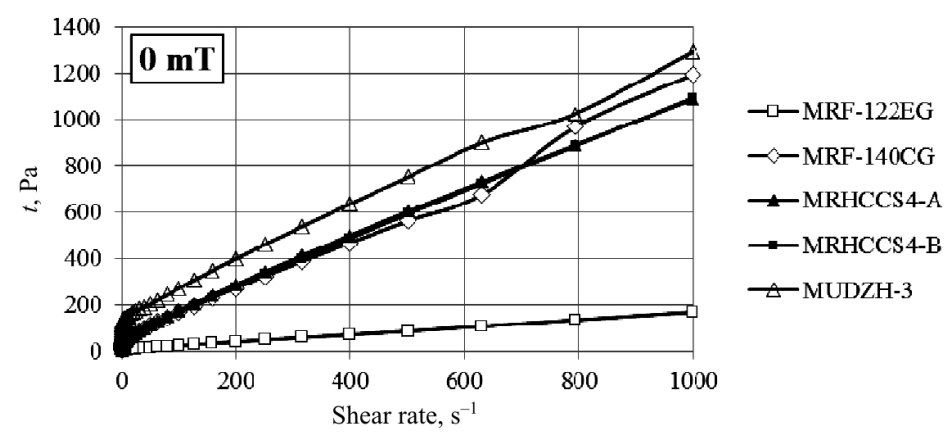

Fig. 4. Viscosity dependence on shear rate when no magnetic field was applied.

fluids. That could be because of additives added to this fluid by Lord Corporation, also it could depend on concentration of particles, because MRF-140CG fluid has higher concentration and the viscosity too. Viscosity of the fluid when no magnetic field applied is important factor when using these fluids in real life applications. It would be better to have as lower viscosity as possible in working device without magnetic field, because that could affect the efficiency of the working device. Ideally, viscosity of the magnetorheological fluids should be lowest when no magnetic field is applied and highest when the magnetic field is applied, but it is really hard to achieve this.

The viscosity dependence on shear rate was also measured in a magnetic field of $0-1$ T. Results are shown in Fig. 5.

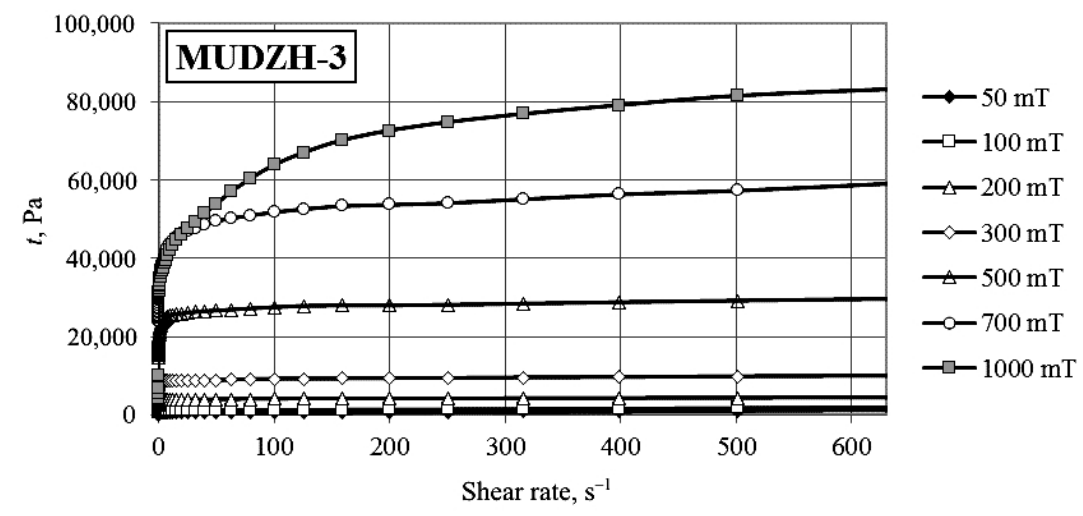

a

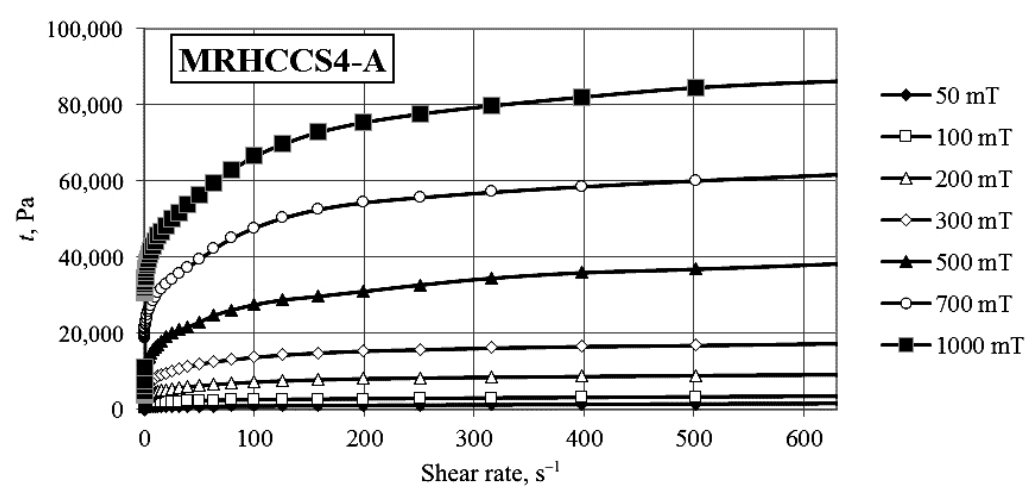



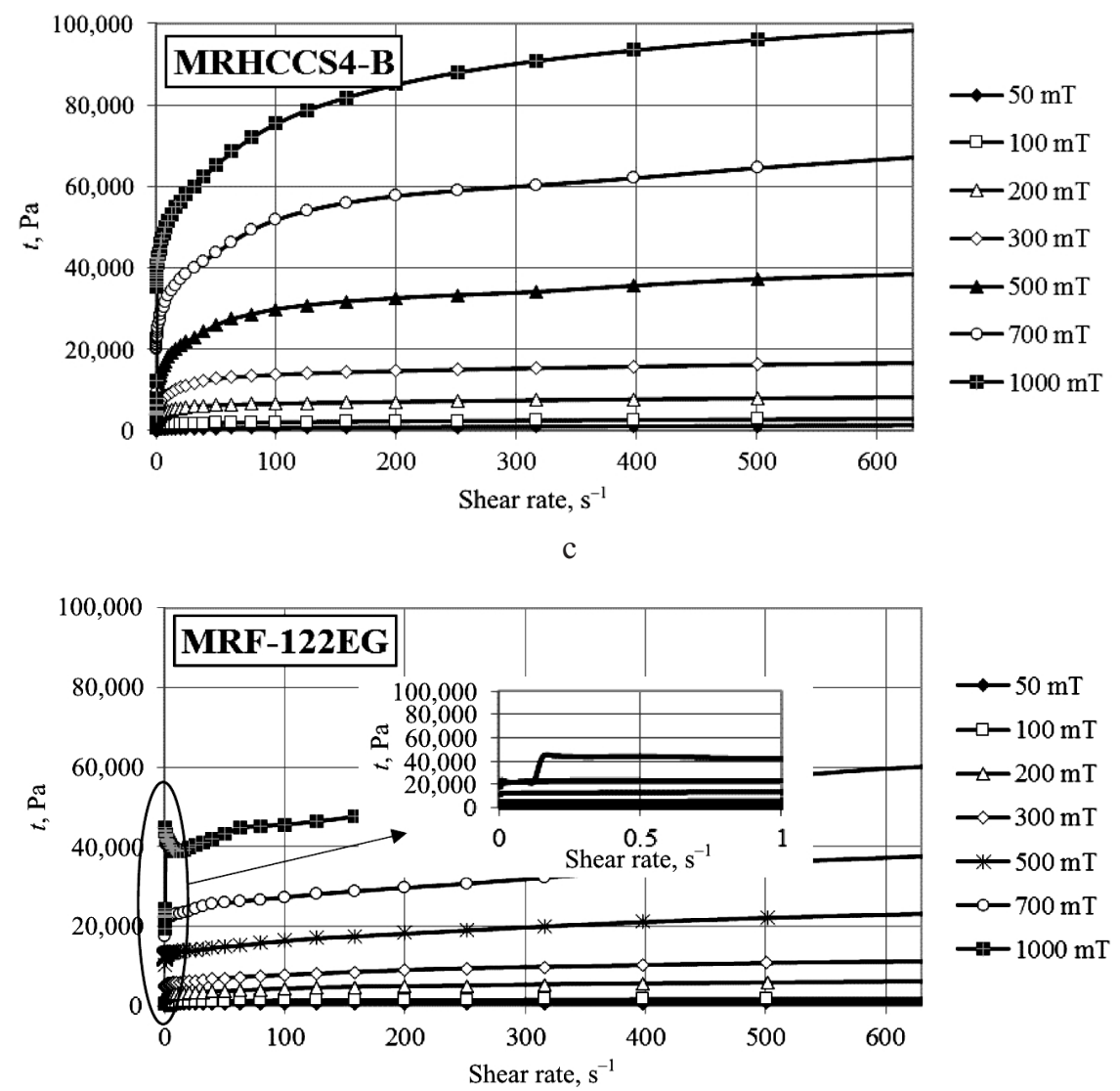

d

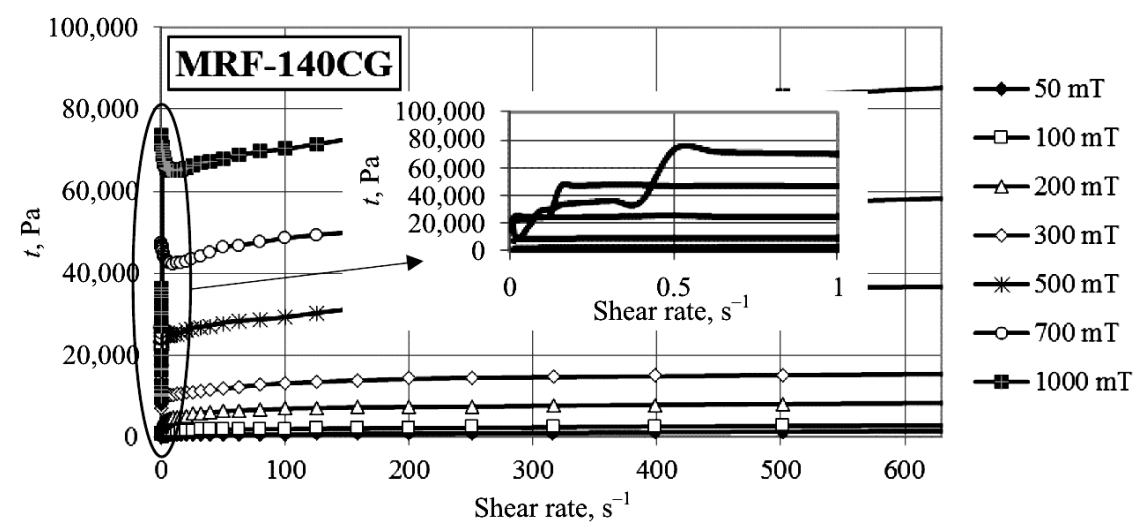

e

Fig. 5. Viscosity dependence on shear rate changing magnetic field for different MR fluids: (a) MUDZH-3; (b) MRHCCS4-A; (c) MRHCCS4-B; (d) MRF122-EG; (e) MRF-140CG.

When a small magnetic field is applied (less than $500 \mathrm{mT}$ ) there is no big difference between all tested fluids. But when $500 \mathrm{mT}$ magnetic field was applied, at high share rates (about 600) viscosity of both Liquids Research Company fluids and MRF-140CG was nearly 40,000 Pa. Furthermore, viscosity of fluid MUZH-3 was less than 30,000 Pa and for MRF-122EG only a little bit more than 20,000 Pa. When $700 \mathrm{mT}$ magnetic field was 
applied at high shear rate fluids MRF-140CG and MUDZH-3 have probably the same viscosity - nearly 60,000 Pa. Fluid MRHCCS4-B has higher viscosity than MRHCCS4-A $(68,000$ and 61,000 Pa). Fluid MRF-122EG has apparently less viscosity than other fluids (less than 40,000 Pa). When maximum tested magnetic field (1 T) was applied, the highest viscosity was for the fluid MRHCCS4-B (nearly 100,000 Pa). Fluid MRF-122EG than has a smallest viscosity of all fluids $(60,000 \mathrm{~Pa})$. Other three fluids have nearly the same viscosity (about 85,000 Pa). Also when there was very low share rate (less than 1 ), both fluids from Lord company have a peeks on higher magnetic field (more than $700 \mathrm{mT}$ ) because the measuring plate of rheometer has slipped.

To determine which of the fluids is the best to use in a real working device magnetic field dependence on the viscosity of MR fluid when the share rate is $500 \mathrm{rps}$ was showed in Fig. 6. As can be seen from the graphs, as it is mentioned previously, MRHCCS4-B is the best fluid to use in a device, and the worst out of these 5 tested fluids is MRF-122EG. Other 3 fluids have nearly the same characteristics.

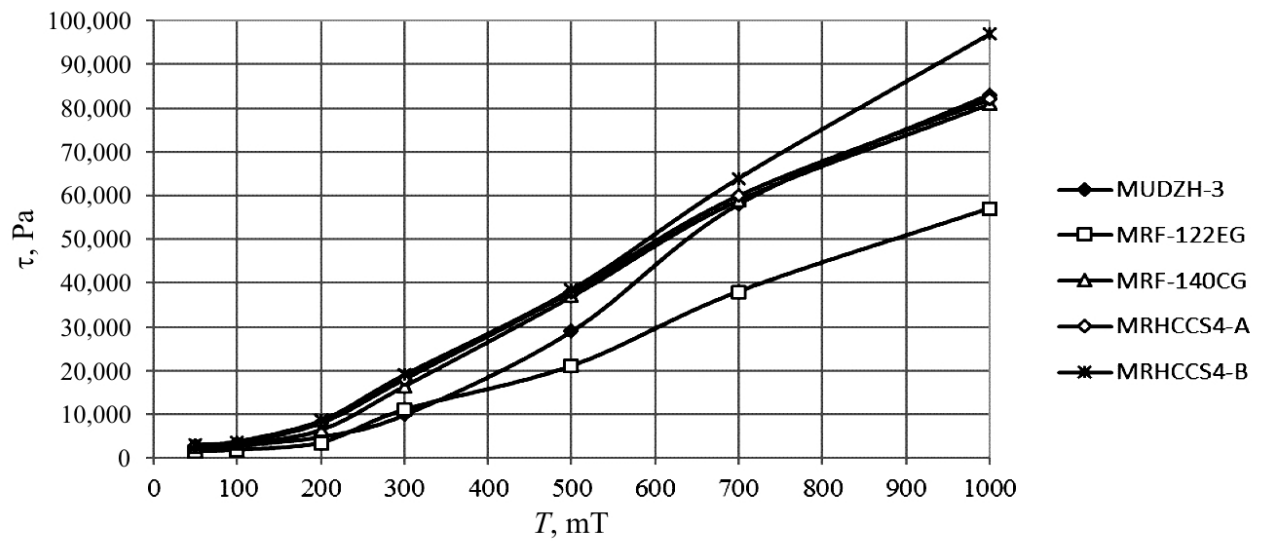

Fig. 6. Magnetic field dependence on the viscosity of MR fluid when the share rate is 500 rps.

By analyzing all results, one can determine that the best fluid for a real life applications is MRHCCS4-B, the worst in this field of testing - MRF-122EG. Although this fluid had the lowest viscosity when no magnetic field was applied, but it also had low viscosity with magnetic field. Other scientists have also measured viscosity using rheometer, but in this paper results differ from them $[25,26]$. MR fluids tested in this paper have really high concentrations $(\sim 70-85 \%)$, so viscosity is higher for them. Some other constructions of rheometer have been described [27-29], but rheometer used in this paper (Anton Paar Physica MCR-301) has got a lot of additional functions and it is quite new.

3.2. Determining a Sedimentation in Magnetorheological Brake. Sedimentation is one of the main thing limiting the usage of magnetorheological fluids. To determine the level of sedimentation in the magnetorheological fluids in literature there are described a few different methods. One of them are using ultrasonic sensors to determine the level of sedimentation [16]. Ultrasonic propagation velocity in MR fluid changes dependent on magnetic field and is related to the sedimentation in this fluid. One more method to determine sedimentation in magnetorheological fluid is to measure their temperature change. One device is heating MR fluid in the lower layer of testing tube, and the other is measuring its temperature. The change of the temperature is depended on concentration of particles, which is settled [10]. For this reason a simple, accurate and easy to adapt method to determine sedimentation using Lithuanian patent ("Device to determine sedimentation in magnetorheological fluids") pending technology have been created. To determine sedimentation inside MR brake its electrical resistivity have been measured. 
Electrical resistivity was measured for 3 days, then 4 piezo-actuators were powered for $1 \mathrm{~min}$ by $2 \mathrm{kHz}$ and the fluid was mixed. The same procedures were carried out after 5 days and after 6 days. Results are shown in Fig. 7. As can be seen, mixing with piezo-actuators stir the fluid, but it can not return initial conditions to the fluid, because residual sedimentation appears. This means that not all particles are mixed, some of them are sticked to the surface of the brake and can't be mixed. Residual sedimentation is increasing during the time a little bit, but until it gets to the point, where all particles in the MR fluid can be mixed. It can be seen the difference between top and bottom sensors resistivity. That is the way how we the sedimentation level could be determined. The higher is the difference between these two sensors, the higher is sedimentation.

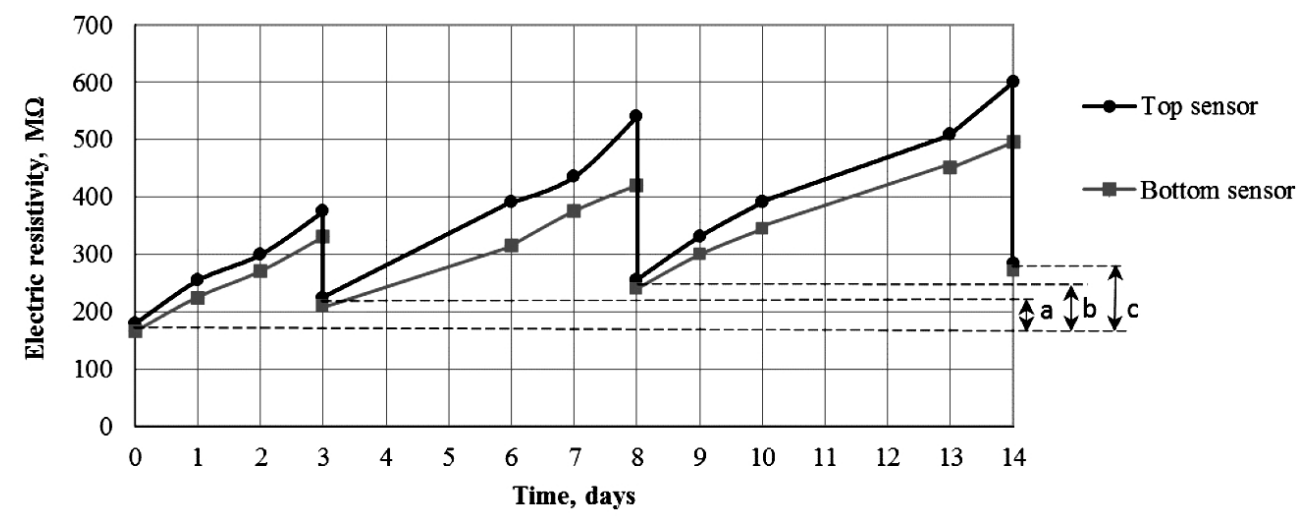

Fig. 7. Determining of the sedimentation in MR brake: (a) residual sedimentation after 3 days; (b) residual sedimentation after 8 days; (c) residual sedimentation after 14 days.

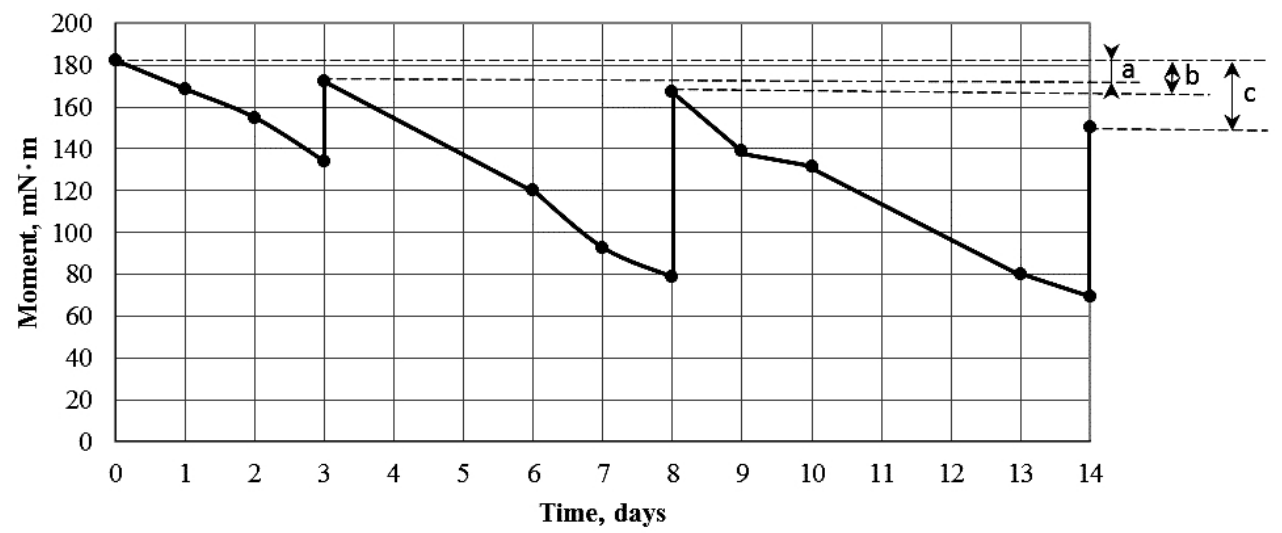

Fig. 8. Torque moments' of the MR brake dependence on time: (a) torque moment affected by residual sedimentation after 3 days; (b) torque moment affected by residual sedimentation after 8 days; (c) torque moment affected by residual sedimentation after 14 days.

There are some articles about using MR fluid for magnetorheological brake [30, 31]. There was measured a torque moment of magnetorheological brake [32], but not tested how sedimentation influences its' torque moment. Sedimentation of the magnetorheological fluids affects the working efficiency of MR brake, that means its' torque moment. The torque moment of the MR brake was measured for 3 days, then mixed by piezo-actuators and after that the same procedures were carried out after 5 days and after 6 days. Results of torque moments' of the MR brake dependence on time are shown in Fig. 8. As can be seen, mixing with piezo-actuators also cannot reach the initial torque moment, because residual 
sedimentation appears. Also it is proved, that when sedimentation in the MR brakes' fluid occurs, its torque moment decreases and it could noticeable decrease the efficiency of the MR brake. If failure occurs in the device which is using MR fluids [30, 33], the proper usage of the device cannot be achieved. This problem can be solved by adding some additives to MR fluid and avoid some failures [1]. If MR fluid does not work properly in the device with its initial conditions, parameters of devices which is set to exact MR fluid cannot be used, because its properties have been changed.

\section{Conclusions}

1. When no magnetic field was applied on the fluid, MUDZH-3 had the highest viscosity (at high shear stress - $1000 \mathrm{rps}$, it is over $1200 \mathrm{~Pa}$ ). MRF-122EG had 6 times lower viscosity than MUDZH-3 (only $180 \mathrm{~Pa}$ at the same share rate). MRHCCS4-A and MRHCCS4-B had almost the same viscosity (over $1000 \mathrm{~Pa}$ at the same share rate). MRF-140CG viscosity was $1200 \mathrm{~Pa}$ at the same share rate. Viscosity with no magnetic field is very important parameter of MR fluids, because it influences a strength which is needed to run a device filled with MR fluid.

2. The viscosity was measured when 0-1 T magnetic field was applied on the fluids. When maximum tested magnetic field (1T) was applied, the highest viscosity was for the fluid MRHCCS4-B (nearly 100,000 Pa). Fluid MRF-122EG than has a smallest viscosity of all fluids $(60,000 \mathrm{~Pa})$. Other three fluids have nearly the same viscosity (about 85,000 Pa). The best fluid should achieve with the highest viscosity under the biggest magnetic field applied, because it influence the strength of the MR fluid itself and how much power it can transfer to the device.

3. The sedimentation level of MR fluid inside tested MR brake was determined by measuring the difference of electric resistivity from top and bottom sensors. It is cheap, easy construction and accurate method to determine sedimentation in MR fluids.

4. The sedimentation of MR fluid inside the brake influences the torque moment of the brake. Also, piezo-actuators mix the fluid, but do not retain its initial conditions.

\section{Резиме}

Досліджується вплив осадження в магнітореологічній рідині на в'язке тертя і крутний момент магнітореологічного гальма. Протестовано п'ять різних магнітореологічних рідин: MRF-140CG і MRF-122EG (корпорація Lord, CША), MRHCCS4-A i MRHCCS4-B (компанія Liquids, Великобританія) та MUDZH-3 (Ін-т тепло- та масообміну ім. О. В. Ликова НАН Білорусі). В'язкість магнітореологічних рідин у магнітному полі інтенсивністю 0-1 Т вимірювали реометром типу Anton Paar Physica MCR-301. Для використання в магнітореологічному гальмі було вибрано рідину з кращими параметрами. Седиментацію в магнітореологічній рідині визначали запатентованим авторами методом, що базується на вимірюванні електроопору рідини. Розроблено математичну модель в'язкого тертя і седиментації в залежності від електроопору рідини. Для змішування рідин всередині магнітореологічного гальма використовували чотири п'єзоприводи. Розроблено експериментальну установку для визначення крутного моменту гальма.

1. M. Ashtiani, S. H. Hashemabadi, and A. Ghaffari, "A review on the magnetorheological fluid preparation and stabilization,” J. Magn. Magn. Mater., 374, 716-730 (2015).

2. M. R. Jolly, J. W. Bender, and J. D. Carlson, "Properties and applications of commercial magnetorheological fluids," J. Intel. Mat. Syst. Str., 10, No. 1, 5-13 (1999). 
3. E. Dragašius, V. Jürènas, V. Mačiukienè, and S. Navickaite, "Investigation of magneto-rheological fluid parameters using cantilever-type piezoactuator," J. Vibroeng., 14, No. 1, 189-195 (2012).

4. D. Mažeika, J. Kunevičius, V. Volkovas, and E. Dragašius, "Research of the flexible bellow with the magnetorheological fluid," J. Vibroeng., 12, No. 4, 472-479 (2010).

5. R. P. Bansevičius, A. Bubulis, E. Dragašius, et al., "Control of piezoelectric scanner dynamics using magnetorheological fluid," J. Vibroeng., 13, No. 4, 755-763 (2011).

6. V. Grigas, E. Dragašius, A. Šulginas, and D. Mažeika, "Evaluation of the resistance force of magnetorheological fluid damper," J. Vibroeng., 14, No. 1, 1-6 (2012).

7. P. Mitrouchev, A. Klevinskis, V. Bučinskas, et al., "Analytical research of damping efficiency and heat generation of magnetorheological damper," Smart Mater. Struct., 26, No. 6, 065026 (2017).

8. G. Z. Yao, F. F. Yap, G. Chen, et al., "MR damper and its application for semi-active control of vehicle suspension system," Mechatronics, 12, No. 7, 963-973 (2002).

9. R. S. Prabakar, C. Sujatha, and S. Narayanan, "Response of a quarter car model with optimal magnetorheological damper parameters," J. Sound Vib., 332, No. 9, 21912206 (2013).

10. I. Bica, "Electrical conductivity of magnetorheological suspensions based on iron microparticles and mineral oil in alternative magnetic field," J. Ind. Eng. Chem., 12, No. 5, 806-810 (2006).

11. F. Zhou, Y. Luo, and H. Ren, "Study of sedimentation stability of magnetorheological fluid," Adv. Mater., 4, No. 1, 1-5 (2015).

12. J. Věžys, E. Dragašius, V. Volkovas, et al., "The sedimentation of magneto-rheological fluid monitoring system based on resistivity measuring," Mechanics, 22, No. 5, 449-452 (2016).

13. S. R. Gorodkin, W. I. Kordonski, E. V. Medvedeva, et al., "A method and device for measurement of a sedimentation constant of magnetorheological fluids," Rev. Sci. Instrum., 71, No. 6, 2476-2480 (2000).

14. Hardeep Singh, Harjot Singh Gill, and S. S. Sehgal, "Synthesis and sedimentation analysis of magneto rheological fluids," Indian J. Sci. Technol., 9 (S1) (2016), DOI: 10.17485/ijst/2016/v9iS1/101472.

15. L. S. Chen and D. Y. Chen, "Permalloy inductor based instrument that measures the sedimentation constant of magnetorheological fluids," Rev. Sci. Instrum., 74, No. 7, 3566-3568 (2003).

16. S. Chen, J. Huang, K. Jian, and J. Ding, Analysis of influence of temperature on magnetorheological fluid and transmission performance, Adv. Mater. Sci. Eng., 2015, 583076 (2015), DOI: 10.1155/2015/583076.

17. Y. T. Choi, L. Xie, and N. M. Wereley, "Testing and analysis of magnetorheological fluid sedimentation in a column using a vertical axis inductance monitoring system," Smart Mater. Str., 25, No. 4, 04LT01 (2016).

18. G. T. Ngatu and N. M. Wereley, "Viscometric and sedimentation characterization of bidisperse magnetorheological fluids," IEEE Trans. Magn., 43, No. 6, 2474-2476 (2007).

19. I. Bica, "The influence of the magnetic field on the electrical magnetoresistance of magnetorheological suspensions," J. Magn. Magn. Mater., 299, No. 2, 412-418 (2006).

20. D. Cohen and I. Nemoto, "Ferrimagnetic particles in the lung. Part 1: The magnetizing process," IEEE T. Bio-Med. Eng., BME-31, No. 3, 261-273 (1984). 
21. MRF-122EG Magneto-Rheological Fluid, http://www.lordmrstore.com/_literature 231216/Data_Sheet_-_MRF-122EG_Magneto-Rheological_Fluid.

22. MRF-140CG Magneto-Rheological Fluid, http://www.lordmrstore.com/_literature 231214/Data_Sheet_-_MRF-140CG_Magneto-Rheological_Fluid.

23. Liquids Research Company Magnetorheological Fluids, http://liquidsresearch.co.uk/ en-GB/magnetorheological_fluids-51.aspx.

24. H. M. Laun, C. Kormann, and N. Willenbacher, "Rheometry on magnetorheological (MR) fluids," Rheol. Acta, 35, No. 5, 417-432 (1996).

25. X. Wang and F. Gordaninejad, "Study of magnetorheological fluids at high shear rates," Rheol. Acta, 45, No. 6, 899-908 (2006).

26. I. D. Jung, M. Kim, and S. J. Park, "A comprehensive viscosity model for micro magnetic particle dispersed in silicone oil," J. Magn. Magn. Mater., 404, 40-44 (2016).

27. S. Odenbach, T. Rylewicz, and M. Heyen, "A rheometer dedicated for the investigation of viscoelastic effects in commercial magnetic fluids," J. Magn. Magn. Mater., 201, Nos. 1-3, 155-158 (1999).

28. S. Kolekar, R. V. Kurahatti, P. K. Prashanth, et al. "Preparation of a silicon oil based magneto rheological fluid and an experimental study of its rheological properties using a plate and cone type rheometer," J. ISSS, 3, No. 1, 19-24 (2014).

29. K. Bashirnezhad, S. Bazri, M. R. Safaei, et al. "Viscosity of nanofluids: a review of recent experimental studies," Int. Commun. Heat Mass, 73, 114-123 (2016).

30. S. A. Wahid, I. Ismail, S. Aid, and M. S. A. Rahim, "Magneto-rheological defects and failures: A review," in: IOP Conference Series: Materials Science and Engineering, Vol. 114, No. 1, 012101 (2016).

31. B. Liu, W. H. Li, P. B. Kosasih, and X. Z. Zhang, "Development of an MR-brakebased haptic device," Smart Mater. Str., 15, No. 6, 1960-1966 (2006), DOI: 10.1088/ 0964-1726/15/6/052.

32. W. H. Li and H. Du, "Design and experimental evaluation of a magnetorheological brake," Int. J. Adv. Manuf. Tech., 21, No. 7, 508-515 (2003).

33. P. P. Phulé, "Magnetorheological (MR) fluids: Principles and applications," Smart Mater. Bull., 2001, No. 2, 7-10 (2001). 